\title{
Nebraska Sedge (Carex nebraskensis Dewey): Observations on Shoot Life History
and Management
}

\author{
RAYMOND D. RATLIFF
}

\begin{abstract}
Nebraska sedge (Carex nebraskensis Dewey), a valuable and distinct species, can withstand a high degree of defoliation by livestock without being seriously damaged. To understand this species better and learn how it can withstand defoliation, shoot life history is being studied on a site in the Sierra National Forest, California. Initial results of the study (overwinter 1979-1980 and the 1980 growing season) indicate that (1) Nebraska sedge shoots live for more than one year; (2) a high proportion of vegetative shoots overwinter; (3) overwintering shoots have cores of live leaf tissue which can develop rapidly in spring; and (4) about half of the shoots surviving winter become reproductive and die. In addition, Nebraska sedge is now recognized as a culmless species. That helps account for its withstanding defoliation. Reproduction appears to be mainly vegetative, and a management goal of producing an abundance of healthy rhizomes is suggested.
\end{abstract}

Nebraska sedge (Carexnebraskensis Dewey) is found from Kansas to California and from New Mexico to Canada (Hermann 1970, Munz and Keck 1959). It is generally palatable to cattle and horses. A valuable species on many mountain meadows, Nebraska sedge is grazed heavily during summer and, in some areas, range managers consider it to be a key species. The foliage of Nebraska sedge is a silvery blue-green distinct from most other sedges. Its distinct color is evident about as soon as a shoot emerges, permitting even young shoots to be identified.

Valuable and distinct as it is, little is known about Nebraska sedge except for its taxonomic relationships. It appears able to stand a high degree of defoliation and not be seriously damaged. But why this is so has remained obscure. The ability to overwinter in a vegetative state may be one reason.

This note reports initial results from an on-going study of Nebraska sedge life history at Tule Meadow on the Sierra National Forest, California. Overwintering (1979-1980) and shoot history during the following growing season (1980) are discussed.

\section{The Study}

Tule Meadow, at an elevation of $2,170 \mathrm{~m}$, lies in a swale formed by moraines (Wood 1975). It is a wet meadow with surface water present most of the time. Beneath the sod surface an organically rich top soil extends to depths of 90 to $120 \mathrm{~cm}$. Soil texture ranges from sand to silt loam. Inorganic, gleyed material extends to 275 $\mathrm{cm}$.

The specific site selected (Fig. 1) is typical of the Nebraska sedge class (Ratliff 1979) and the wet meadow, Nebraska Sedge Association (MW19 11) (Hall 1979). Other species prevalent on the site include beaked sedge (Carex rostrata Stokes) and tufted hairgrass (Deschampsia caespitosa (L.) Beauv.). Soil is typically that of Nebraska sedge sites in the Sierra Nevada. Such sites have a loam texture, a strongly acid reaction, and more than $20 \%$ organic matter at the 10- to 20-cm depth (Ratliff 1979).

The author is a range scientist with the Pacific Southwest Forest and Range Experiment Station, USDA, Forest Service, Berkeley, Calif., stationed at 2081 E. Sierra Ave., Fresno, Calif. 93710.

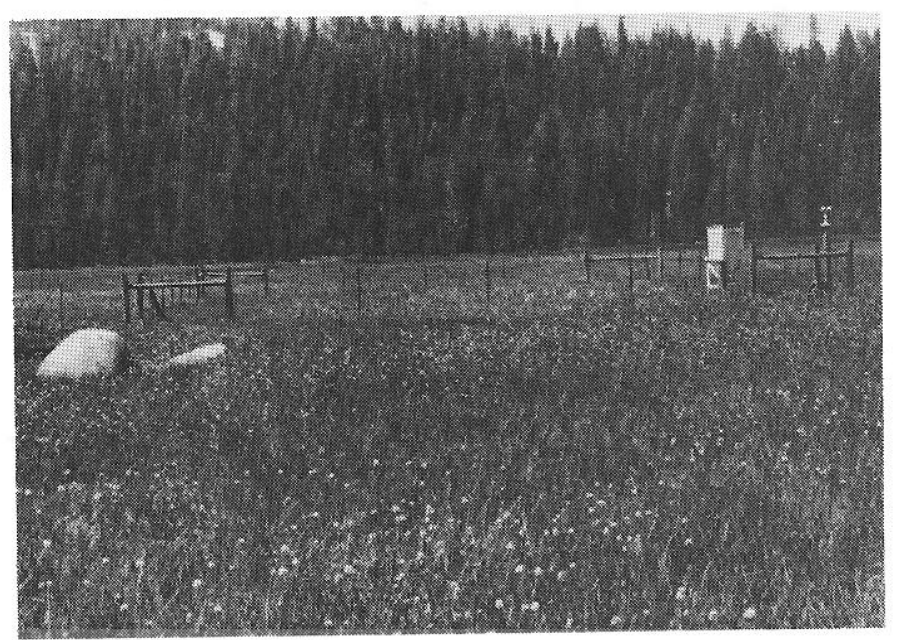

Fig. 1. Nebraska sedge study site, Tule Meadow, Sierra National Forest, California, July 31, 1980.

An exclosure was established on the site to prevent disturbance of this and companion studies on shoot morphology, carbohydrate trends, and biomass dynamics. Within the exclosure specific areas were designated for each activity. For this study a $10 \mathrm{~m}$ by $0.5 \mathrm{~m}$ study area was divided into 40 possible plots. Ten of these were randomly selected and staked. Thus, the experimental design used was a simple random sample from a finite population.

Each plot was $1 / 8 \mathrm{~m}^{2}(25$ by $50 \mathrm{~cm})$. That size plot was large enough to assure its containing a number of shoots of Nebraska sedge. It was small enough to assure detection of new shoots and to permit efficient observation of older shoots.

In early December 1979, I tagged 267 shoots of Nebraska sedge found in the 10 plots. These were well developed, mature shoots, having produced several leaves during the 1979 growing season. Also, they had a central core of live, green tissue. Stainless steel wires attached to numbered plastic tags were loosely tied around the shoot bases. Bernard (1976) used numbered metal clips in his study of beaked sedge.

On April 10,1980, snow on the the plots was $1.5 \mathrm{~m}$ deep. By May 8 the snow was melting and some ground could be seen, but the plots were not fully accessible until May 22. From then until November 20,1 observed the plots biweekly and recorded changes in phenology of the individual shoots. Shoots that survived and remained vegetative were not considered to advance again through the younger stages.

Data analy sis consisted of determining the $95 \%$ confidence intervals for percentages of vegetative, reproductive, and dead shoots found on selected dates through the study period.

\section{Results and Discussion}

On May 22, immediately after the snow melted from the plots, $96 \%$ of the shoots still had a core of live tissue (Fig. 2), but there was no new growth. 


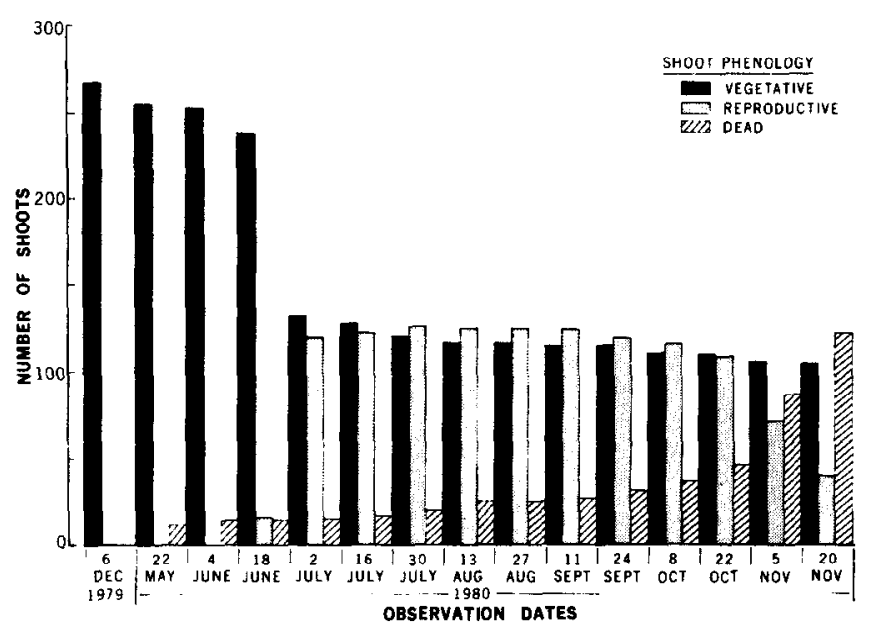

Fig. 2. Life history of 267 mature Nebraska sedge shoots from December 1979 to November 1980.

On June 4,95\% of the shoots remained, and there was some new growth. Overwinter survival was $94.8 \%(P[92.2 \%<\mu<97.3 \%]=$ 0.95 ). Winter mortality, therefore, accounted for between $3 \%$ and $8 \%$ of the mature vegetative shoots tagged the previous December. By mid-June the surviving shoots had produced an abundance of new foliage, and $6 \%$ of the shoots were in an early reproductive stage. The inflorescences were low in the boot and not above the basal leaves. Two weeks later, $48 \%$ of the remaining live shoots were reproductive. Culms were well elongated and the inflorescences were fully visible, but anthesis had not begun.

By July 30, the reproductive shoots were in full bloom. They comprised slightly more than $51 \%(P[39.9<\mu<62.2 \%]=0.95)$ of the 247 shoots alive at that time and $50 \%$ of the overwintered shoots. The period of full bloom lasted until mid-August. From then until late September seed was ripening. Before the end of Septemer, $5 \%$ of the 126 reproductive shoots were dead and another $44 \%$ were showing signs of senescence. By early November, $43 \%$ of them were dead. The $32 \%$ left at the last observation (Nov. 20) had minimal green tissue remaining were dying.

Seventeen percent of the 127 shoots that stayed vegetative died during the course of the season. By November, most of the outer leaf tissue on the remaining vegetative shoots was dead. Some green tissue, however, was present on the lower portions of some leaf blades, and the core of live tissue was present. Therefore, of the 253 overwintered shoots, $41.5 \%(P[29.6 \%<\mu<53.4 \%]=0.95)$ were prepared for another winter.

Like Nebraska sedge, overwintering shoots of beaked sedge have a core of live tissue. Such shoots are mature and vegetative and will flower in their second growing season (Bernard 1976). Depending upon when they emerge, shoots of beaked sedge may live for 18 to 24 months. Nebraska sedge shoots may live longer. I do not know how old the shoots were in fall 1979. Some surely emerged that season, and they may be the ones that remained vegetative. However, they were mature when tagged. The Nebraska sedge shoots now into their second (known) winter have seen two growing seasons and may see a third.

I have found that Nebraska sedge has the same characteristics as described for culmless grasses (Hyder 1972). The apical meristems of vegetative shoots of Nebraska sedge are near or below ground level through the growing period. The sources of leaf material are below the usual level of defoliation resulting from grazing. Because the meristems are not removed, the shoots can continue to produce new leaves as long as environmental conditions remain favorable. Only when a shoot becomes reproductive is its growing point elevated. The ratio of reproductive to vegetative shoots is relatively low. On July 30 , the ratio was about $1: 2$, with new shoots of the 1980 growing season included in determining the ratio. Nebraska sedge is, thus, a "culmless"species-a fact that helps account for its ability to withstand defoliation.

Bernard (1975) reported having never found a seedling of beaked sedge. Reproduction of that species is mainly vegetative. That, also, appears to be the principal means by which a population of Nebraska sedge is maintained. Mature shoots of Nebraska sedge removed for study of seasonal carbohyd rate trends (Steele 1981) were mostly from rhizomes. This was true, also, for shoots that emerged during the growing season and developing but not emerged shoots in the fall. Some tillers were, however, present. I found only 12 seeds in several mature spikes, and I have yet to identify a seedling of Nebraska sedge in the field. Therefore, 1 suggest that management to produce an abundance of healthy rhizomes is a more viable goal than management to produce a Nebraska sedge seed crop.

\section{Conclusions}

Much remains to be learned about Nebraska sedge. Nevertheless, it is now possible to tentatively draw the following conclusions.

1. Shoots of Nebraska sedge can live for 2 or more growing seasons.

2. A high proportion of overwintering shoots normally survive.

3. Overwintering shoots have cores of leaf tissue which can develop and begin photosynthesis as soon as the temperatures warm sufficiently. Renewed growth, thercfore, may occur early in the spring.

4. Around half of the overwintered shoots will become reproductive and die during the following fall and winter.

Many new shoots of Nebraska sedge emerged in the plots during 1980. All have been tagged. I am following their development (along with the remainder of the shoots considered in this paper) to more fully understand Nebraska sedge life history and management requirements. While the final conclusions from this study must be considered specific for the finite population being studied at Tule Meadow, I am confident they will hold for Nebraska sedge throughout the Sierra Nevada.

\section{Literature Cited}

Bernard, J.M. 1975. The life history of shoots of Carex lacustris. Can. J. bot. 53:256-260.

Bernard, J.M. 1976. The life history and population dynamics of shoots of Carex rostrata. J. Ecol. 64:1045-1048.

Hall, F.C. 1979. Codes for Pacific Northwest Ecoclass Vegetation Classification. USDA, Forest Serv., Pacific Northwest Region. R-6 Ecol. 79-002.

Hermann, F.J. 1970. Manual of the carices of the Rocky Mountains and Colorado Basin. USDA, Forest Serv. Agr. Handbk. No. 374.

Hyder, D.N. 1972. Defoliation in relation to vegetation growth. P. 304-317. In: V.B. Younger and C.M. McKell (eds.), The Biology and Utilization of Grasses. Academic Press, New York.

Munz, P.A., and D.D. Keck. 1959. A California Flora. Univ. of California Press. Berkeley.

Ratliff, R.D. 1979. Meadow sites of the Sierra Nevada, California: Classification and species relationships. Ph.D. Diss. New Mexico State Univ., Las Cruces.

Steele, J. 1981. Seasonal variation in total available carbohydrates in Nebraska sedge (Carex nebraskensis). M.S. Thesis, California State Univ., Fresno.

Wood, S.H. 1975. Holocene stratigraphy and chronology of mountain meadows, Sierra Nevada, California. Ph.D. Diss. California Inst. of Technol., Pasadena. 